\title{
The use of forest resources in central Iberia during the Late Iron Age. Insights from the wood charcoal analysis of Pintia, a Vaccaean oppidum
}

\author{
Juan M. Rubiales ${ }^{\mathrm{a}, *}$, Laura Hernández ${ }^{\mathrm{a}, \mathrm{b}}$, Fernando Romero ${ }^{\mathrm{c}}$, Carlos Sanz ${ }^{\mathrm{c}}$ \\ ${ }^{a}$ Departamento de Silvopascicultura, Escuela Técnica Superior de Ingenieros de Montes, Universidad Politécnica de Madrid, Ciudad Universitaria s/n, Madrid, Spain \\ ${ }^{\mathrm{b}}$ Departamento de Selvicultura y Gestión Forestal Sostenible, INIA-CIFOR, Crta. La Coruña km 7.5, Madrid, Spain \\ ${ }^{\mathrm{c}}$ Departamento de Prehistoria y Arqueología, Universidad de Valladolid, Valladolid, Spain
}

\section{A R T I C L E I N F O}

\section{Article history:}

Received 8 March 2010

Received in revised form

24 June 2010

Accepted 1 July 2010

\section{Keywords:}

Anthracology

Palaeoethnobotany

Wood use

Human behavioral ecology

Holocene

Northern meseta

Spain

\begin{abstract}
A B S T R A C T
Charred woods may be used to effectively reconstruct past wood acquisition strategies. We used anthracological data from the pre-Roman settlement of Pintia (Padilla de Duero, Valladolid) to examine the use of forest resources at the local scale. Palaeoecological data revealed heterogeneous landscapes in the inland northern meseta with environments that offered diverse sources of wood for the inhabitants of Pintia, one of the first cities of inland Iberia. Pines (Pinus pinea/pinaster and Pinus sylvestris/nigra) and both evergreen and deciduous Quercus L. and Juniperus L. were the main taxa identified as both fuelwood and construction elements, but the assemblages and frequencies of these taxa differed depending on their use. We also examined the potential of models from human ecology by considering the frequency, handling time and the relative technological value of each taxon to model how people gathered wood resources. The results suggest that although local availability affected the forest resources that were used by the Vaccaei people, specific taxa were positively selected for specific uses.
\end{abstract}

(c) 2010 Elsevier Ltd. All rights reserved.

\section{Introduction}

Archaeological charred remains have been widely employed to reconstruct the composition and structure of woody vegetation from the past. Classical anthracological studies in the Mediterranean region have usually focused on the potential of charcoal assemblages from hearths as important sources of information on the plant communities that surrounded the archaeological sites (see Chabal et al., 1999; Asouti and Austin, 2005). Although longlasting pyrotechnic contexts are recognized as excellent targets of study when creating palaeo-environmental reconstructions, methodological constraints arise, and the interpretations are frequently subjected to filters conditioning the assemblages (Smart and Hoffman, 1988; Dufraisse, 2008; Théry-Parisot et al., 2010). The principle of least effort (which assumes that charcoal frequency reflects, with a direct or nearly direct correspondence, the prevalence of woody taxa) was commonly employed to interpret the results of archaeological charcoal findings. However, charred remains are the final result of diverse human activities; consequently, archaeological charcoals are not haphazardly distributed by the sole effect of climatic and environmental conditions. Methods for the ecological interpretation of plant remains from

\footnotetext{
* Corresponding author.

E-mail address: jm.rubiales@upm.es (J.M. Rubiales).
}

anthropogenic combustion elements are well developed and established (e.g., Chabal, 1992; Figueiral, 1993; Badal et al., 1994; Vernet, 1997), but few studies successfully deepen the value and understanding of the charcoal assemblages from pyrotechnic and non-pyrotechnic features. Furthermore, few studies have focused on the human behavioral perspective (but see Figueiral, 1996; Buxó and Piqué, 2008; Marston, 2009).

The study of wood acquisition strategies from diverse areas of activity (including construction elements or tools) remains a challenging undertaking because it is difficult to accurately model diverse and coupled human and natural processes. This paper focuses on data from a pre-Roman settlement located in the Spanish northern meseta. In these archaeological contexts, research on human behavior has been mostly developed from other areas of investigation, such as analyses of artistic legacy, artifacts, urbanism or diet (see Romero et al., 1993; Delibes et al., 1995; Sanz and Velasco, 2003). The aim of this paper is to address the patterns of resource usage and access information from an archaeobotanical perspective based on traces that can be monitored archaeologically. First, we examine the archaeological significance of the anthracological record of Pintia, one of the most important settlements in the Duero basin prior to and during the Roman invasion. Second, this work explores the use of charcoal assemblages in human behavior by means of an optimal foraging model to understand the patterns of wood acquisition in the past. 


\section{Ecological and archaeological contexts}

The archaeological site of Pintia $\left(41^{\circ} 36^{\prime} 24\right.$ N, $4^{\circ} 6^{\prime} 48 \mathrm{~W}, 775 \mathrm{~m}$ a.s.l.) is located between Padilla de Duero and Pesquera de Duero, close to the town of Peñafiel (Valladolid, Spain). Geographically, it is placed in the center of the Spanish northern meseta in the sedimentary inland plains of the Duero basin and close to the riverbanks of the Duero River (Fig. 1). It lies near the base of limestone plateaus that are about $100 \mathrm{~m}$ above the valley's bottom (800-900 $\mathrm{m}$ a.s.l.) and that have some small gypsum outcrops on their hillsides. It is positioned at the northwestern edge of the Tierra de Pinares region. One of the features that characterize the Tierra de Pinares region is the late-Quaternary sandy aeolian sediments that fill a large area of the Duero basin (approx. $1000 \mathrm{~km}^{2}$ ). The climate is Continental-Mediterranean, with cold winters and dry and warm summers (three months of summer drought). The local mean annual temperature is about $10^{\circ} \mathrm{C}$, and the mean annual rainfall is $c a .610 \mathrm{~mm}$.

The region is characterized by intense human exploitation that has been carried out on the fertile Duero alluvial plain during the last millennia. The long-lasting human activity has left a patched landscape with agricultural systems and scattered forest stands. Among them, holm oak coppice forests (Quercus ilex subsp. ballota (Desf.) Samp.) with several Juniperus species (Juniperus oxycedrus L., Juniperus communis L. and Juniperus thurifera L.) are found on the limestone plateaus, together with sub-Mediterranean deciduous oaks (Quercus faginea Lam.) growing on moister soils and/or north-facing slopes. Pinewoods (from which the name Tierra de Pinares is derived) are primarily associated with thick aeolian sand sheets. This type of forest has relatively low species diversity and includes Pinus pinaster Ait. and Pinus pinea L. as principal species. Some Pinus halepensis Mill. afforestations (and also $P$. pinea and $P$. pinaster) can also be found along the hill slopes. Other relevant woody species in the area are hawthorn (Crataegus monogyna Jacq.), thorny broom (Genista scorpius (L.) DC.), Lithodora fruticosa (L.) Griseb., Lepidium subulatum L. (on gypsum soils) and other medium and small shrubs of the families Cistaceae, Labiatae and Leguminosae (i.e., Cistus laurifolius L., Halimium sp., Lavandula latifolia Medicus, Thymus spp., Salvia lavandulifolia Vahl, Ononis tridentata L., and Dorycnium pentaphyllum Scop.). Today, riparian environments remain heavily disturbed by human activities but support diverse woody hygrophilous vegetation dominated by several tree species (Alnus glutinosa (L.) Gaertn., Ulmus minor Mill., Fraxinus angustifolia Vahl., Salix alba L., Salix eleagnos Scop., Salix triandra L. and Tamarix sp.).

Pintia is a multi-period urban settlement with a sequence of occupations from the Iron Age (5th to 4th centuries BC) through the Medieval Age until the 7th century AD (Sanz and Velasco, 2003). The site reached its maximum size during the Vaccaean period (late Iron Age), when the settlement stretched for over 125 ha. At this time, three main differentiated areas existed: the necropolis of "Las Ruedas", the artisan neighborhood of "Carralaceña" and the fortified village of "Las Quintanas" (Sanz and Velasco, 2003, Fig. 2). Archaeological excavations, directed by Carlos Sanz and Fernando Romero since 1979, have been developed along a trench of $8 \mathrm{~m} \times 56 \mathrm{~m}$ that is divided into seven square sectors of $8 \mathrm{~m}$ on each side (Fig. 3, A-G). Three cultural stages of occupation have been recognized: (i) late-Roman and Visigothic, (ii) Roman, and (iii) Vaccaean (Velasco et al., 2003). The stratigraphic sequence begins in the upper levels with a Visigothic necropolis that is imprecisely dated (beginning probably in the 3rd century AD and including burials from up to the 7th century AD). The burial area was set on the most modern Roman level, which is heavily altered due to that the stones that were used by the Romans for the foundations of their houses where also used by the Visigothics as graves. This level includes several stages of occupation, although the scarcity of remains from this period points to a long and progressive abandonment that probably began during the 3rd century AD (Sanz et al., 2009). The charcoals that were analyzed in this study originate in the most modern level of the Vaccaean occupation (dated to the 1 st century $\mathrm{BC}$ ) and to the phases below (up to the 4th century $\mathrm{BC}$ ). The important layers of ashes appearing in these periods indicate fire events that may be linked with the Civil and Sertorian

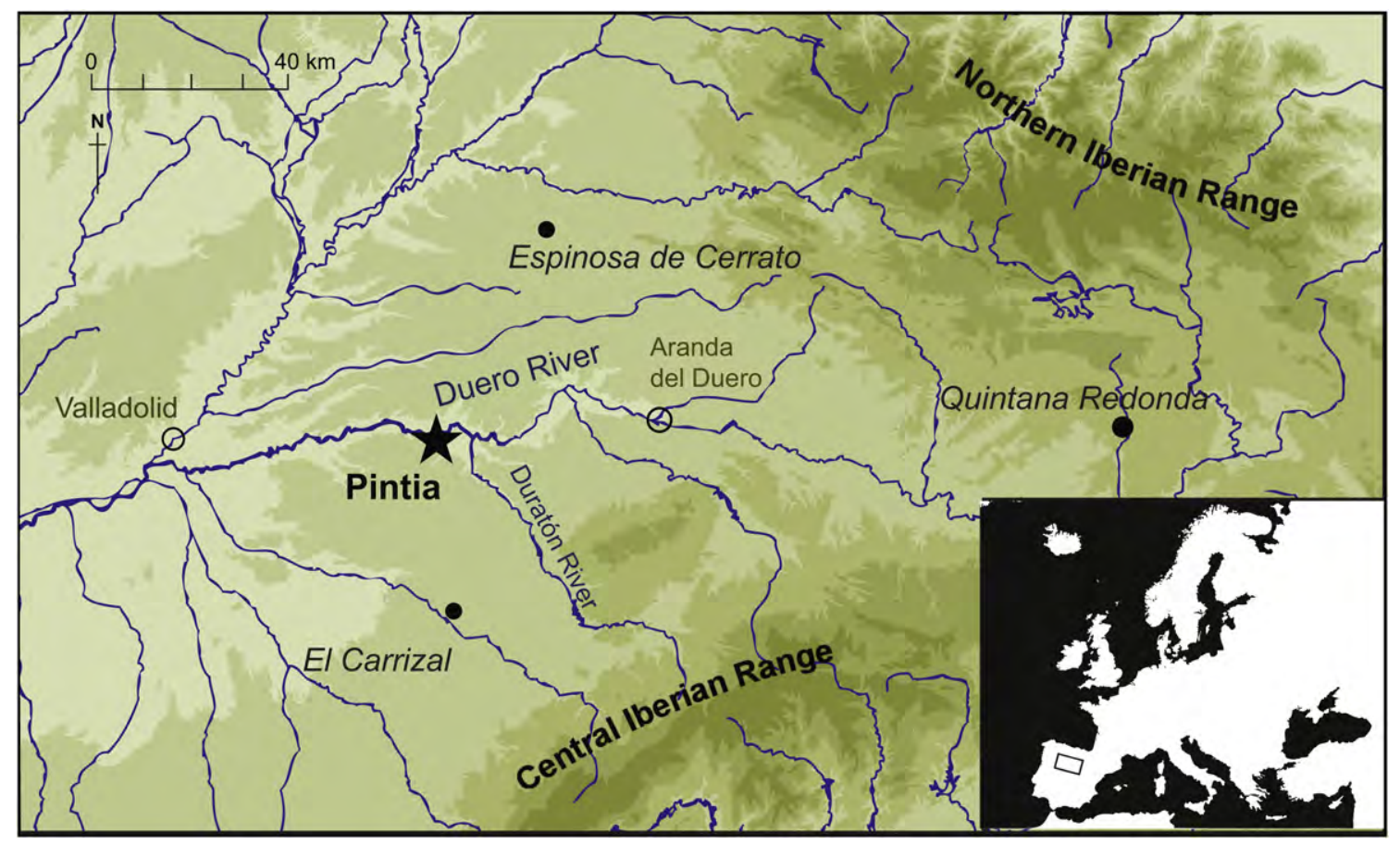

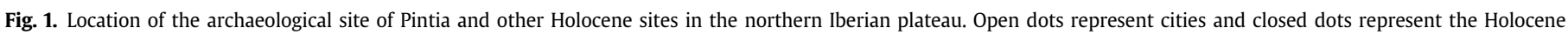
palynological sites mentioned in the text. 


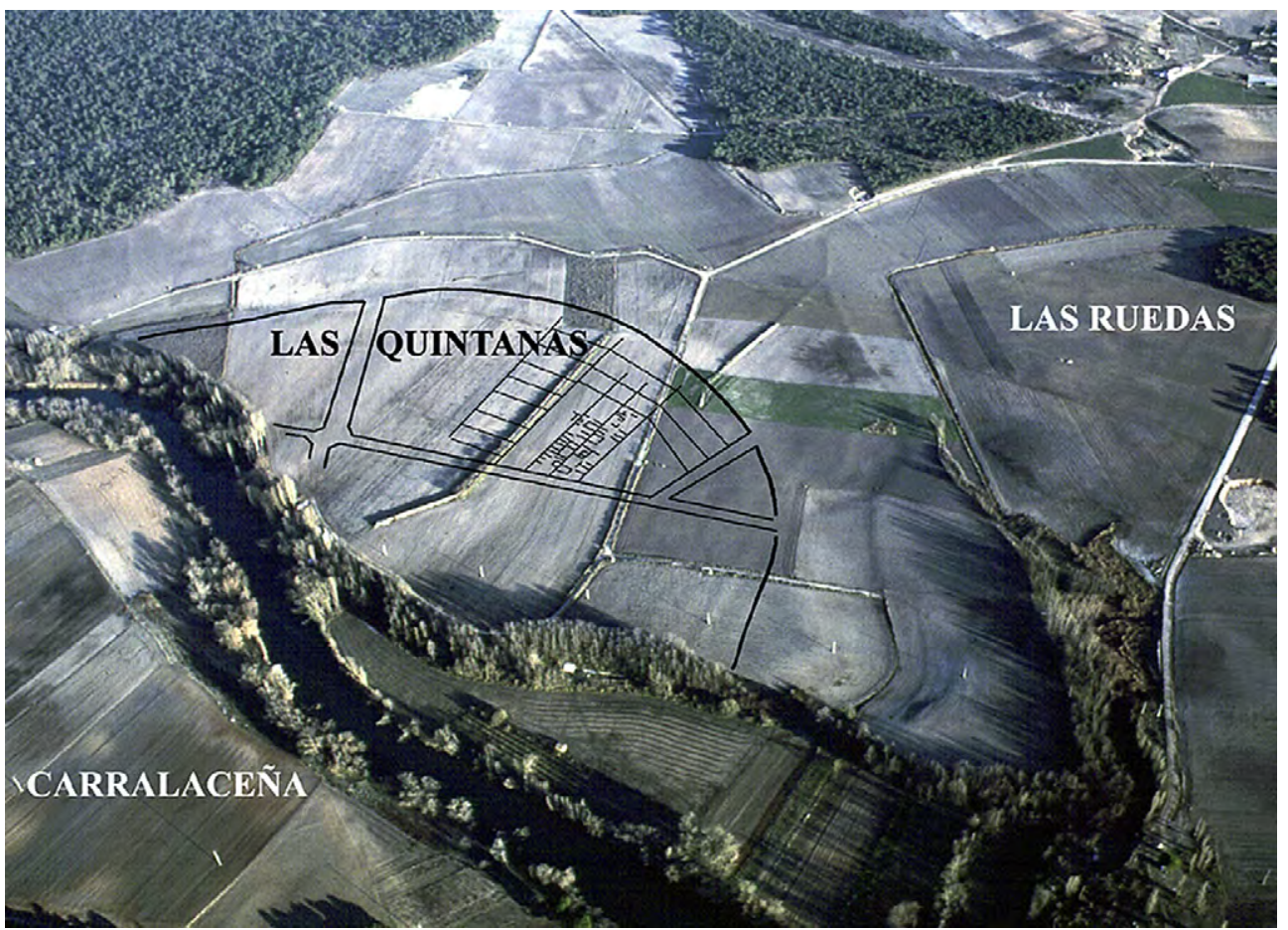

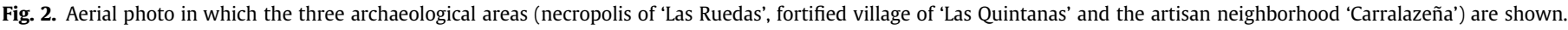
Anthracological investigations were carried out in the zone labeled 'Las Quintanas'.

wars. Vaccaei communities developed a particular land usage model, concentrating the population in relatively large urban settlements (known as oppida) with important economic and political influences (Sanz and Velasco, 2003). The urban typology to which the studied remains belong has been considered to correspond to one of the first cities of inland Iberia (Álvarez-Sanchís, 2005).

\section{Materials and methods}

The results from the charcoal analysis are based on the anatomical study of 744 charcoal samples that were obtained from all of the stratigraphical units that were excavated in Pintia between 1998 and 2006. The charcoal fragments were handpicked by the archaeological team of the University of Valladolid and recovered throughout the archaeological layers corresponding to the Vaccaean and Vaccaean-Roman ages of the village ("Las Quintanas" zone). The origin of the charcoals is diverse. Charcoal appearing in the structures of houses, ditches, post-holes and pits was identified as charcoal from construction elements, while charcoal recovered from hearths and domestic fire places was characterized as fuelwood. The fairly good state of preservation of the charcoals allowed the identification of most of the samples to the species level. However, in some cases, different taphonomic processes (i.e., vitrification, fragmentation, and insect and fungi degradation) resulted in poor preservation and caused problems in identifying distinctive anatomical characteristics.

Charcoal fragments were fractured manually to obtain clear surfaces for microscopic analysis: transversal, radial and tangential sections were created. Anatomical features were observed by reflected-light microscopy at different magnifications $(\times 50, \times 100$ and $\times 200$ ). Taxonomic identification was achieved using keys and atlases of wood anatomy identification (e.g., Greguss, 1955; Jacquiot, 1955; Peraza, 1964; García and Guindeo, 1988; Schweingruber, 1990; Vernet et al., 2001) and by comparison with the wood reference collection of the Universidad Politécnica de Madrid. For identification at the species level, special attention was paid to the discrimination between Pinus specimens. However, as most of the remains were not identified at the species level, for the purposes of this study samples were classified into two morphotypes: those presenting large pinoid (fenestriform) pits were classified as Pinus sylvestris/nigra and those with small pinoid (oval) pits were classified as P. pinaster/pinea. This feature can be observed in the radial section (Fig. 4).

To address why and how the Vaccaei may have chosen specific wood types for fuel or construction, we followed the methods described by Marston (2009), which construct rank orders of resource types based on three variables: value (based on the technological features of each wood type), time handling (distance) and frequency (occurrence). For structural wood used for construction purposes, pieces of an appropriate size are needed. Furthermore, cylindrical pieces that are resistant to compression, bending and durability are highly desirable. A rank order was created based on these features that assigned weighted values to each of the parameters. Details for this classification are given in the captions of Table 1 and Fig. 5.

For the estimation of the value of fuelwood, the fuel-value index (FVI) was calculated. The FVI is an index defined by the formula given by Bhatt and Todaria (1992) that ranks fuel according to the three most important features that define fuelwood suitability: heating value (HVV), wood density and ash content (Table 2).

$\mathrm{FVI}=(\mathrm{CV} \times$ density $) / \mathrm{AC}$, where $\mathrm{CV}$ is the HVV of oven-dried $\operatorname{wood}\left(\mathrm{kJ} \mathrm{g}^{-1}\right), \mathrm{AC}$ is the ash content $\left(\mathrm{g} \mathrm{g}^{-1}\right)$, and density is in $\mathrm{g} \mathrm{cm}^{-3}$.

Thus, high calorific value, high density and low ash content are considered to be good fuelwood properties. The FVI was applied to the data available for Iberian taxa or, in the absence of such data, for the nearest analogous taxon for which data were available.

The relative contribution of each variable to the behavioral patterns that drive wood gathering was tested independently against the charcoal dataset using Kendall's tau, a nonparametric measure of correlation. The rank orders are created based on (i) 


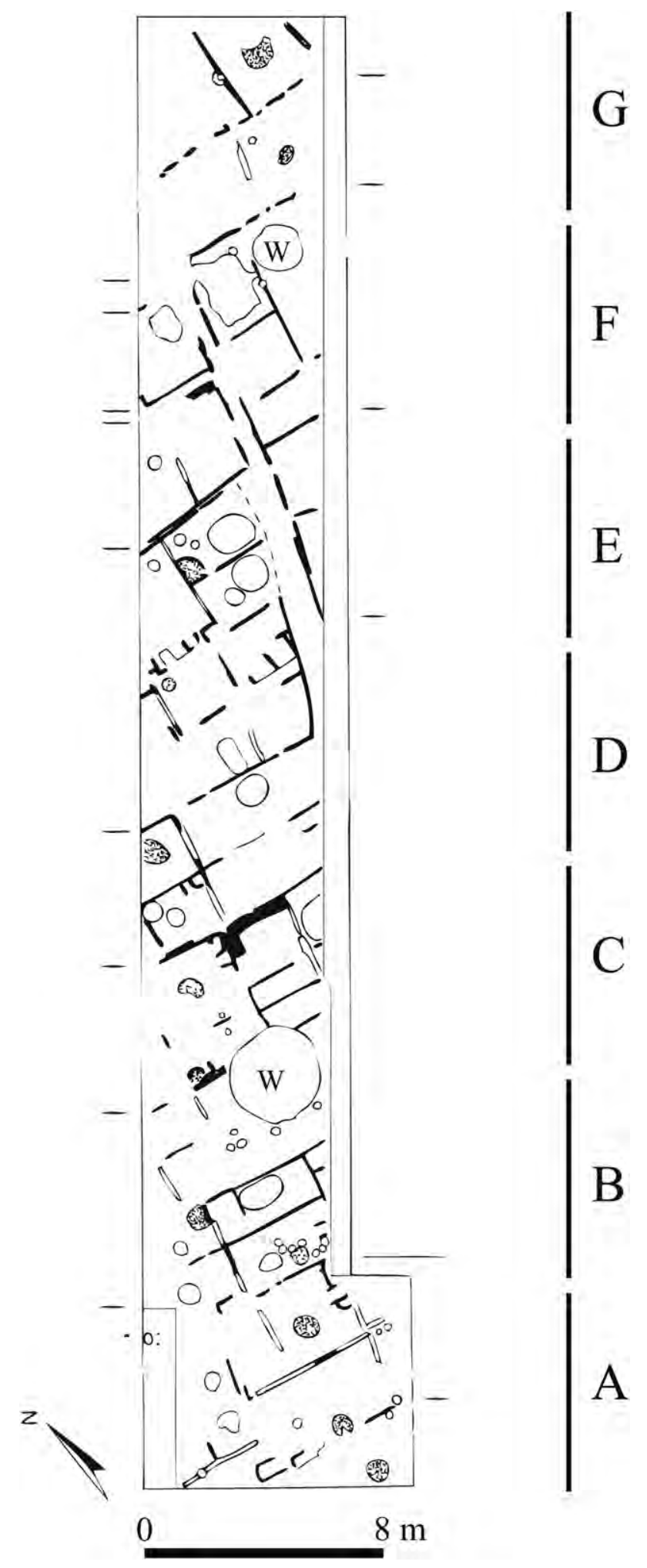

Fig. 3. Map showing the excavated area and the placement of hearths and domestic fires (shaded areas) and wells (W).

descriptions in published sources and (ii) observations during field surveys (see Tables 1-5). A statistical analysis was performed with the open-source software R (http://www.R-project.org) and the additional software package KENDALL (McLeod, 2005).

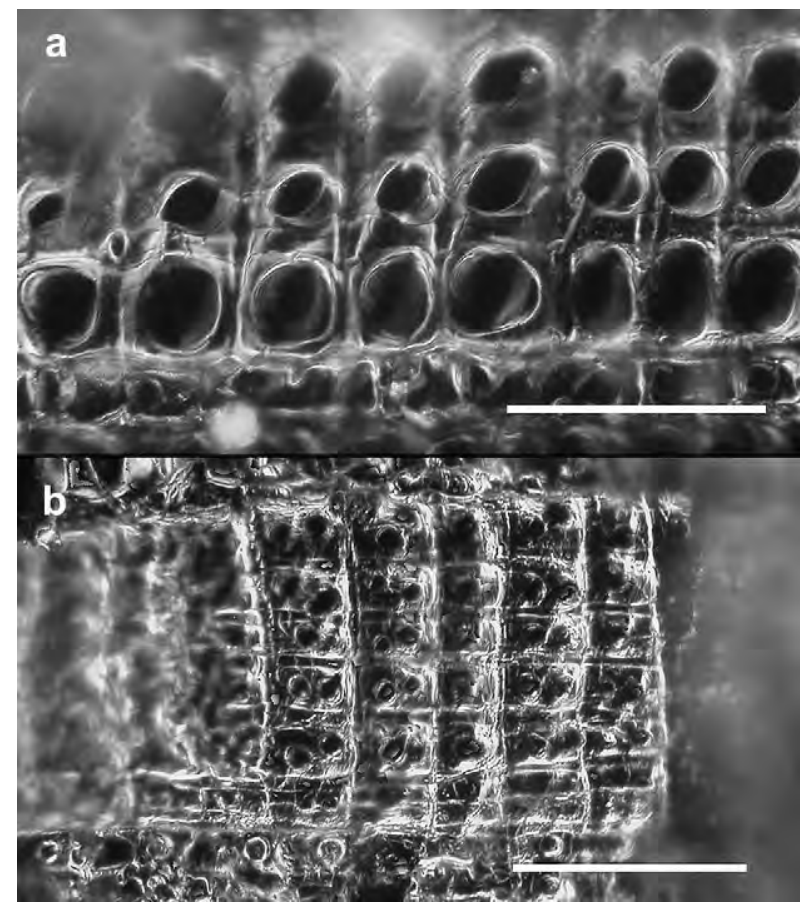

Fig. 4. Radial section of the two morphotypes identified for the genus Pinus. (a) Pinus sylvestris/nigra, large pinoid (fenestriform) pits and (b) Pinus pinaster/pinea, small pinoid (oval) pits. Scale bar $=0.1 \mathrm{~mm}$.

\section{Results}

Twelve taxa were identified in the charcoal assemblage, including both Mediterranean and Eurosiberian taxa. The most common Mediterranean elements that were detected included evergreen oak (Quercus subgenus Sclerophyllodris), genuine Mediterranean pines (such as $P$. pinaster and $P$. pinea) and junipers (Juniperus spp.).

Although in some of these groups the anatomical features do not allow separation of the charcoals at the species level, ecological and biogeographical information is useful for better interpretation of the assemblage with precise taxa. In the case of the evergreen Quercus, three main species occur in Iberia. Because holm oak ( $Q$. ilex subsp ballota) is adapted to the continental Mediterranean climate, it primarily grows in areas of cold (and even dry) winters in central Spain, also tolerating the harsh conditions of the inland summer (severe drought and high temperatures). Other species of the evergreen group dominate forests in other areas of Iberia that are characterized by warmer Mediterranean climates; consequently, their existence in the area surrounding the site is highly unlikely. Likewise, cork oak (Quercus suber) grows primarily in southwestern Iberia on siliceous soils, and kermes oak (Quercus coccifera, also belonging to the subgenus Sclerophyllodris) is a typical element from maquis and coppice forests in the coastal area. The remains of sclerophyllous oaks that were recovered in our charcoal assemblage fit better with the ecology of the first species described ( $Q$. ilex subsp ballota).

Regarding the identification of deciduous Quercus, two marcescent species commonly occur in inland Spain, namely, Quercus pyrenaica and $Q$. faginea. Both species require, when growing under the drought-influenced climate, sub-humid environments to persist. Under this framework, northern slopes and uplands, and occasionally the riparian buffers, are the most suitable areas for deciduous oaks. However, because $Q$. pyrenaica shows calcifuge behavior, available niches point to $Q$. faginea as the most suitable oak species growing in the surroundings of the study site. 
Table 1

Rank order for wood construction value based on log shape, durability and mechanical resistance (axial compression and bending strength). Corylus, Ilex and Crataegus are ranked in last place (8), as their size and shape are not suitable for beams and pillars. Data obtained from Cigalat and Soler (2003).

\begin{tabular}{llllrl}
\hline & $\begin{array}{l}\text { Log } \\
\text { shape }\end{array}$ & Durability & $\begin{array}{l}\text { Axial } \\
\text { compression } \\
\text { strength }\left(\mathrm{kg} / \mathrm{cm}^{2}\right)\end{array}$ & $\begin{array}{l}\text { Bending } \\
\text { strength } \\
\left(\mathrm{kg} / \mathrm{cm}^{2}\right)\end{array}$ & $\begin{array}{l}\text { Rank } \\
\text { order }\end{array}$ \\
\hline Quercus evergreen & $* *$ & $*$ & 660 & 970 & 6 \\
Quercus deciduous & ${ }^{* *}$ & $*$ & 600 & 1200 & 2 \\
Pinus sylvestris/nigra & ${ }^{* * *}$ & $* *$ & 475 & 1000 & 2 \\
Pinus pinaster/pinea & ${ }^{* * * *}$ & $* *$ & 400 & 800 & 6 \\
Juniperus & $* * * *$ & $* * * *$ & 520 & 1050 & 1 \\
Castanea & $* *$ & $*$ & 720 & 950 & 4 \\
Fraxinus & $* * *$ & - & 560 & 1400 & 4 \\
\hline
\end{tabular}

All four species of pines that were included in the two taxonomic groups reported from the wood anatomy are ecologically compatible for the site. Today, the species included in the most important group ( $P$. pinaster and $P$. pinea) grow at nearby locations, dominating extensive forests over the sandy sediments of Tierra de Pinares. In contrast, $P$. sylvestris and $P$. nigra do not currently exist in the area and may have suffered from local extinctions over the basin. Some relict populations of the latter two species (the only ones in the central Duero basin) have been detected in a scenario that shares geomorphologic similarities with the surroundings of Pintia. Relic stands are linked mostly to the wooded buffer of the river Cega near Cuéllar (approx. $30 \mathrm{~km}$ to the south of Pintia). $P$. nigra grows mostly on unstable soils on the sunniest slopes of the river's banks, and $P$. sylvestris is present both in shaded zones of the river's buffer and in the Navazo de los Valsaines, an area of seasonally saturated soils.
Table 2

List of species and their rank orders for fuel value based on (a) published caloric values of HVV for woody taxa and (b) the fuel-value index (FVI) calculated by the formula given by Bhatt and Todaria (1992) that considers the heating value (HVV), density of the wood and the ash content. Data for the building of both ranks were taken from Graves (1919), Siafaca et al. (1980), Bossel (1980) in Reisinger et al. (2009), Nuñez-Regueira et al. (2001a,b), Domínguez et al. (2003), Viquerat et al. (2006), Camps and Marcos (2008) and Tolosana et al. (2008).

\begin{tabular}{llcc}
\hline & Relative HVV value & HVV Rank order & FVI Rank order \\
\hline Quercus evergreen & 0.935 & 4 & 5 \\
Quercus deciduous & 0.892 & 6 & 2 \\
Pinus sylvestris/nigra & 0.991 & 2 & 2 \\
Pinus pinaster/pinea $^{\text {a }}$ & 1.000 & 1 & 3 \\
Juniperus $_{\text {Castanea }}$ & 0.985 & 3 & 1 \\
Corylus & 0.801 & 9 & 8 \\
Ilex aquifolium & 0.844 & 8 & 6 \\
Fraxinus & 0.691 & 10 & 10 \\
Crataegus & 0.858 & 7 & 7 \\
\hline
\end{tabular}

a A relative HVV value of 1 corresponds to Pinus pinaster/pinea.

Three of the six native species of junipers that currently grow in the Iberian Peninsula are compatible with the charcoal assemblage and occur regionally. Spanish juniper (J. thurifera) forests are distributed widely in eastern inland Iberia, and the species also appears in conjunction with other tree species such as $Q$. ilex, $Q$. faginea and $P$. nigra. Furthermore, J. communis and J. oxycedrus are widely found in Quercus/Pinus forests, although they rarely become dominant.

Several trees and shrubs associated with the Euro-Siberian-type deciduous floristic element are also sporadically present in the charcoal assemblage, such as chestnut (Castanea), ash (Fraxinus), hazelnut(Corylus), holly tree (Ilex) and Rosaceae (subfam. Maloideae),

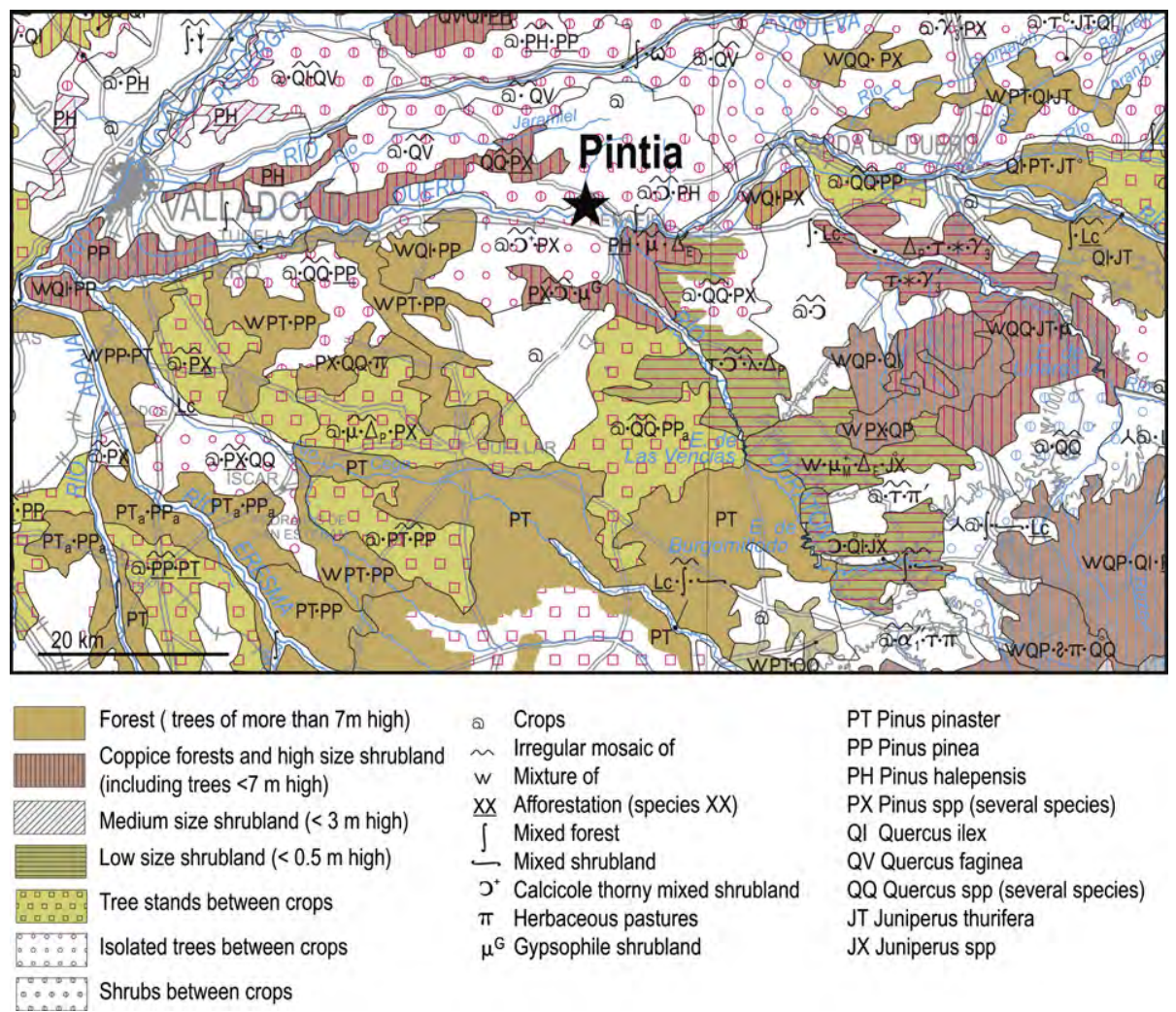

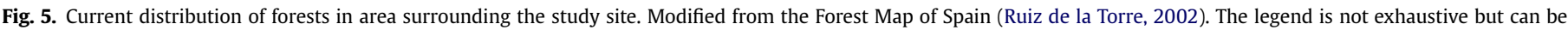
entirely found in the cited source. 
Table 3

Archaeological rankings based on the number of fragments and ubiquity of (a) construction elements and (b) pyrotechnic contexts.

\begin{tabular}{|c|c|c|c|c|}
\hline & $\begin{array}{l}\text { Absolute fragment count percentages } \\
\text { referring to the entire assemblage }\end{array}$ & $\begin{array}{l}\text { Rank based on absolute } \\
\text { counting of fragments }\end{array}$ & $\begin{array}{l}\text { Ubiquity percentages referring to } \\
\text { the ensemble of the studied zones }\end{array}$ & $\begin{array}{l}\text { Rank based } \\
\text { on ubiquity }\end{array}$ \\
\hline \multicolumn{5}{|l|}{ (a) } \\
\hline Quercus ilex & 9.3 & 5 & 18.9 & 4 \\
\hline Quercus deciduous & 11.2 & 4 & 18.9 & 4 \\
\hline Pinus sylvestris/nigra & 18.5 & 3 & 31.1 & 3 \\
\hline Pinus pinaster/pinea & 33.1 & 1 & 43.2 & 1 \\
\hline Juniperus & 22.5 & 2 & 32.4 & 2 \\
\hline Castanea & 0.6 & 7 & 2.7 & 6 \\
\hline Corylus & 0.3 & 8 & 1.4 & 8 \\
\hline Ilex & 4.5 & 6 & 2.7 & 6 \\
\hline Fraxinus & 0.0 & 9 & 0.0 & 9 \\
\hline $\begin{array}{l}\text { Crataegus } \\
\text { (b) }\end{array}$ & 0.0 & 9 & 0.0 & 9 \\
\hline Quercus ilex & 42.7 & 1 & 41.7 & 1 \\
\hline Quercus deciduous & 5.5 & 6 & 16.7 & 5 \\
\hline Pinus sylvestris/nigra & 15.0 & 2 & 41.7 & 1 \\
\hline Pinus pinaster/pinea & 12.7 & 3 & 36.1 & 3 \\
\hline Juniperus & 2.7 & 8 & 11.1 & 6 \\
\hline Castanea & 6.4 & 5 & 19.4 & 4 \\
\hline Corylus & 0.0 & 9 & 0.0 & 9 \\
\hline Ilex & 0.0 & 9 & 0.0 & 9 \\
\hline Fraxinus & 5.0 & 7 & 11.1 & 6 \\
\hline Crataegus & 10.0 & 4 & 11.1 & 6 \\
\hline
\end{tabular}

which probably corresponds to the hawthorn (Crataegus type). Although Castanea is reported as a native element in Iberia, palaeoecological evidence suggests that the use of chestnuts was spread throughout the Roman Empire (Conedera et al., 2004); in the case of the northern meseta, this could represent one of the earliest cultivated fruit species in the region. However, we are not aware of archaeological findings of edible sweet chestnuts in Vaccaean or early-Roman times in central Iberia. The data for uses such as tool elaboration are not reported in the statistical analysis due to the small sample size ( $<20$ samples), but it is remarkable that the wood selected for this use always belonged to deciduous Quercus.

Concerning the results of the bivariate statistical analysis, there is a strong and positive significant correlation between ranks; either they were based on absolute fragment counts or on ubiquity (Kendall's Tau values of 0.977 for construction wood types and 0.858 for fuelwood, $p<0.05$; Table 5 ). This finding indicates that both datasets are substantially similar for the purpose of the analysis; consequently, the statistical inferences made from them and presented in this work are analogous.

\section{Table 4}

Rank orders of distance and frequency for the species detected by the charcoal assemblage. Ordered lists for frequency and distance for extant taxa were created based on relative species abundance in the region today based on data from the Forest Map of Spain (Ruiz de la Torre, 1990-1998, 2002, see Fig. 5) and an in situ botanical survey. For locally extinct species, the former distribution was hypothesized based on the ecological context and by comparisons with nearby locations. For distance, values of 1-4 are given considering the mean distance to which the species could have been. The values for frequency indicate the following: $1-$ very frequent (large area), 2 - frequent, 3 - scarce, 4 - very scarce, 5 - exceptional (the values 4 and 5 are given to the taxa occurring only in the riparian buffer).

\begin{tabular}{lll}
\hline & Distance & Frequency \\
\hline Quercus evergreen & 2 & 1 \\
Quercus deciduous & 4 & 2 \\
Pinus sylvestris/nigra & 3 & 3 \\
Pinus pinaster/pinea & 4 & 1 \\
Juniperus & 4 & 2 \\
Castanea & 3 & 4 \\
Corylus & 1 & 4 \\
Ilex & 2 & 5 \\
Fraxinus & 1 & 4 \\
Crataegus & 1 & 2 \\
\hline
\end{tabular}

The test results for fuelwood and construction wood are summarized in Table 5. As expected, no correlation was found between ranks of fuelwood and construction, depicting an active selection for wood gathering depending on the uses involved. For fuelwood, HVV values and charcoal representation show a weak correlation (Kendall's tau $=0.494, p \approx 0.06$ based on absolute counting and $0.471, p \approx 0.08$ based on ubiquity) and the frequency was also weakly correlated with a Kendall's tau value of 0.562 $(p<0.05)$ with absolute counting ( $\operatorname{tau}=0.513, p \approx 0.08)$. No correlation was found when the FVI or distance was used.

The results for construction wood do not reflect a significant $(p<0.05)$ statistical correlation for either the construction value or the frequency rank orders. However, there was a clear negative correlation with the distance ranking $(-0.786, p<0.05)$, indicating that some species were positively selected regardless of their distance to the site.

Table 5

Results from the bi-variate analysis using the Kendall's tau for all of the possible pairs of ranks that were studied. (abs: absolute counting of fragments; ub: ubiquity; cons: wood construction value; HVV: heating value; FVI: fuel value index). Significant $(p<0.05)$ correlations are marked with an asterisk.

\begin{tabular}{lcc}
\hline & Tau & $\begin{array}{l}2 \text {-sided } \\
p \text { value }\end{array}$ \\
\hline Construction (abs) vs Construction (ub) & $0.977^{*}$ & 0.0002 \\
Pyrotechnic (abs) vs Pyrotechnic (ub) & $0.858^{*}$ & 0.0013 \\
Construction (abs) vs Pyrotechnic (abs) & 0.159 & 0.5885 \\
Construction (ub) vs Pyrotechnic (ub) & 0.390 & 0.1649 \\
Construction (abs) vs Properties (cons) & 0.435 & 0.1168 \\
Construction (abs) vs Distance & $-0.768^{*}$ & 0.0051 \\
Construction (abs) vs Frequency & 0.367 & 0.1933 \\
Construction (ub) vs Properties (cons) & 0.445 & 0.1141 \\
Construction (ub) vs Distance & $-0.786^{*}$ & 0.0048 \\
Construction (ub) vs Frequency & 0.426 & 0.1342 \\
Pyrotechnic (abs) vs Properties (HVV) & 0.494 & 0.0593 \\
Pyrotechnic (abs) vs Properties (FVI) & 0.114 & 0.7184 \\
Pyrotechnic (abs) vs Distance & -0.099 & 0.7795 \\
Pyrotechnic (abs) vs Frequency & $0.562^{*}$ & 0.0409 \\
Pyrotechnic (ub) vs Properties (HVV) & 0.471 & 0.0820 \\
Pyrotechnic (ub) vs Properties (FVI) & 0.310 & 0.2702 \\
Pyrotechnic (ub) vs Distance & -0.286 & 0.3423 \\
Pyrotechnic (ub) vs Frequency & 0.513 & 0.0723 \\
\hline
\end{tabular}




\section{Discussion}

\subsection{Representativeness of the charcoal assemblage under human selection}

There is a common agreement among archaeobotanists that man is the main factor affecting the representativeness of charcoal assemblages in human environments. The recent updated review by Théry-Parisot et al. (2010) illustrates well the potential effects of the so-called "societal filter" that appears to be a key question with respect to the human practices that reflect incidences for the assemblages of paramount importance. Beyond the principle of least effort, further developed theories on optimal human foraging have been applied to charcoal assemblages to address the roles of factors defining human activity, such as the availability of resources, the duration of charcoal accumulation and/or the charcoal remains distributions (e.g., Badal, 1992; Chabal, 1997; Carrión, 2005).

It is worth noting that the charcoal assemblages that were obtained in this study fit well with the information provided by other palaeoecological studies and, besides the societal filter, they provide useful data for reconstruction of the vegetation history during the late Holocene in the Duero basin. Other palynological studies have also recorded the importance of pines in sandy environments throughout the whole Holocene (Franco et al., 2005; Díez et al., 2002; Mariscal, 1995; Mariscal et al., 1995; Ruiz Zapata, 1995; Yll, 1995). This finding is consistent with the preliminary results obtained from other studies based on macro-charcoals in the same geographical context (Uzquiano, 1995). Pines are frequently accompanied by evergreen and deciduous Quercus that become more abundant in the plateaus (Franco et al., 2001, 2005). Nevertheless, the high proportion of Juniperus detected in the anthracological record is, to some extent, unexpected when compared with pollen archives. High resin and oil content make juniper wood especially resistant to decay, and several other additional positive attributes (e.g., good odor and cylindrical and resistant stems; Ceballos and Ruiz de la Torre, 1971) may have contributed to the over-representation of wood in the charcoal assemblage, probably due to a higher frequency of use. Furthermore, Juniperus pollen grains disperse less than those of pines and are rather thin-walled, often suffering important degradation processes that may result in lower pollen percentages being recorded on pollen diagrams than expected. A third reason that may have resulted in the higher abundance of this taxon in the charcoal dataset is the location of the site, as most of the study sites that have been previously studied in the region are confined to the lowlands. Pintia's assemblages cover the palaeoecological signal at the base of limestone hills that may have been at the edge of the distribution area of juniper forests that are nowadays extensively distributed further east. Historical references to these forests have been found in the work of Strabo, cited in Wattenberg (1959).

Charcoals of Pinus offer complementary taxonomic information to pollen identification and reveal the importance of pines from the group $P$. sylvestris/nigra. This taxonomic group of species is currently extinct in the area, so this information is of great interest. P. nigra could have been widely distributed (although not with great frequency) in the early and middle Holocene on top of the limestone hills, together with junipers and probably mixed with evergreen and deciduous Quercus, as suggested by other palaeoecological data from the eastern Duero basin (Franco et al., 2001; Moreno et al., 2009; García Amorena et al., in prep). In contrast, $P$. sylvestris may have persisted under specific soil conditions (soils with acidic humus layers). However, both species of highland pines are considered to be highly sensitive to anthropogenic disturbances, especially the effects of fires of either climatic or human origin (e.g., Rubiales et al., 2007). Under such a scenario, fire-resilient communities and re-sprouters would have been favored over $P$. sylvestris and/or $P$. nigra, and the selective and long-lasting wood exploitation process may have regionally aggravated the regression of the forests.

\subsection{Contextualizing the uses of fuelwood and construction wood from archaeological, historical and ethno-botanical data}

Anthracological records from other pre-Roman sites of northwest Iberia also report the important use of evergreen and deciduous Quercus and P. pinaster as fuelwood and/or construction elements. (e.g., Figueiral, 1996; Figueiral and Bettencourt, 2004). In eastern Iberia, the presence of $P$. sylvestris/nigra and deciduous Quercus in the assemblages (either for construction or fuelwood) is notably higher. Both taxa have been found in the same period in Teruel (Cubero, 2000), while highland pine (P. nigra/sylvestris) remains have been broadly found in settlements at Alicante (Uzquiano and Arnanz, 1997), Castellón (Oliver, 2006), RequenaUtiel (Mata, 1991; Haro, 2002), and numerous locations in Catalonia (e.g., Alonso, 1999; Allué, 2003; Piqué, 2005; Piqué and Pons, 2007). Beams of deciduous Quercus were also widely found for the same period (e.g., Piqué and Ros, 2002; Rocafiguera, 2005).

Other historical references and modern ethno-botanical studies for the northern meseta also contribute to the contextualization, from a societal perspective, of the results obtained in this work. These data report that traditional forest resources include either oaks, pines or junipers as trees for fuelwood in the nearby regions (Blanco, 1998, 2003; Oria de Rueda and Díez, 2002; Ramos, 2005a; Gil, 2008). When various species occur simultaneously, oaks seem to be preferred over junipers or pines due to the higher quality of embers and durability (e.g., Álvarez et al., 1990; Ramos, 2005b; Oria de Rueda, 2007). In addition, there are presumable negative health effects associated with burning juniper wood (migraine), which would be due to their resins and volatile compounds (Álvarez et al., 1990). Ethnobotanical literature also reports the extensive use of small pieces of pine imbued in resin (especially of $P$. nigra, $P$. sylvestris and $P$. pinaster) as kindling (Oria de Rueda and Díez, 2002). Finally, among the Mediterranean species of Quercus used as fuelwood, historical data point to $Q$. ilex as being generally preferred over Q. faginea (Guerra and Fernández, 2001) and show an active and extensive reforestation with this species from the 16th century onwards (Calonge and Ramos, 2006; Ramos, 2005b).

The selection of wood for construction purposes has been traditionally directed towards conifers (genera Pinus and Juniperus). The durability of the wood of these trees together with the large sizes commonly attained and the cylindrical shape of their stems makes them the best of all species coexisting in the area for beams, pillars and lintels (e.g., Blanco, 1998), as the charcoal assemblage suggests. The historical information recovered by Rodríguez (2008) and the dendrochronological features of the wood of several churches and monasteries of the Duero basin confirm these statements for the Early Middle Age: the group $P$. sylvestris/nigra is identified in some architectural components of the Burgalese churches of Quintanilla de las Viñas (pre-Romanic) and Sta Cecilia de Barrosuso (Romanic) as well as in the Visigothic churches of San Pedro de la Nave (Zamora) and San Juan de Baños (Palencia), which were dated to the 7th century AD. Furthermore, the importance of conifers as significant construction elements throughout time can be gauged from further usage that extends through the High Middle Ages, such as the reconstructions of the monastery of Silos (which occurred ca. $1390 \mathrm{AD}$ and reportedly used P. sylvestris) or in the Romanic church of San Miguel del Caltojar (beginning of the 13th century 
AD), where both $P$. sylvestris and $P$. pinaster were used (Rodríguez, 2008).

\subsection{Wood-gathering strategies for construction and fuelwood uses}

The lack of correlation between ranks for fuelwood and construction elements illustrates the active selection process of wood gathering depending on its use. However, it seems clear that the four most distributed woody taxa (P. pinaster/pinea, P. sylvestris/ nigra, Quercus and Juniperus) were primarily used for both purposes. The strategic position of the site, located in an area of transition between sandy sediments (Tierra de Pinares) and limestone plateaus, together with riparian environments and wetlands, allowed the inhabitants to choose between various environments with different wood resources when they gathered wood, resulting in the differences observed in both datasets.

Nevertheless, selection does not seem to be driven by a unique factor. It could have been expected from this analysis that the resources would have been selected based on their technological value (whether for fuelwood or construction), distance to the settlement or frequency with which the resource appears. However, the results do not support this hypothesis. Except for a positive (but discrete) correlation between fuelwood ranks and frequency ( $0.562 p<0.05$, absolute abundance), neither fuel value ranks nor construction attributes were significantly correlated with the frequency of archaeological charcoal in the assemblages representing those uses. Consequently, our results indicate that the Vaccaei communities inhabiting Pintia were not uniquely attending to the relative value of each taxon when using forest resources for construction or fuel. Furthermore, the commonly presented hypothesis that the species closer to the settlement would be positively selected is not supported by our data. Even less expected is the finding that for construction woods, charcoal representation is significantly and negatively correlated with distance ranks $(-0.786, p<0.01)$. This result could be explained by the likelihood that some high-quality products used for construction (such as junipers and pines) would be highly valued and selected regardless of their distance from the site. It seems reasonable that the need for more durable materials for important purposes (such as housing) would justify additional efforts, which, in this case, would imply a larger distance for transport. Although in a very different context, the same case was reported by Marston (2009). The principle of least effort would be not valid for these kinds of activities, but our data discretely support the validity of the principle of least effort when wood is recovered to be used as fuel.

Concerning fuelwood, the weak correspondence between charcoal representation and value may be due to several reasons. First, the two combustion properties chosen in this study, the FVI and HVV, may not represent the most important criteria for human choices. In the case of the Iberian woods used in this work, the available data were necessarily obtained from different sources (see caption in Table 2), resulting in possible heterogeneity in the methodological procedures that may affect comparisons, even when considering rankings. In addition, noticeable differences have been found between close taxonomic groups, even in the same species. For instance, in our case study, there exist wide differences in values for $P$. pinaster $\left(\mathrm{HVV}_{20}\right.$ ranging from $17,075 \mathrm{~kJ} / \mathrm{kg}$ to $15,354 \mathrm{~kJ} / \mathrm{kg}$ ) depending on the resin content (Camps and Marcos, 2008). Second, wood properties undoubtedly depend on the species, though other combustion properties, such as moisture, size, odor and ease of ignition, may be important for their performance as fuel. Among the latter characteristics, water content, which largely depends on the season of wood gathering, is probably the most important feature (Théry-Parisot, 2001; Nuñez-Regueira et al., 1997, 2001a).

\section{Concluding remarks}

To maximize our capacity to understand and interpret assemblages of archaeological charcoal, we must consider the possible interference of human systems, especially if the data are used to model past vegetation. The strategic location of the Vaccaean oppidum studied in this work (Pintia) would certainly confer some plasticity to the inhabitants of the settlement in the exploitation of forest resources. River buffers, swampy areas, sandy environments and limestone plateaus were all certainly used differently depending on the objectives of the inhabitants. Our results confirm the existence of the selection of woody resources carried out in a preRoman city using models of behavioral ecology that have been previously explored in other areas of the Mediterranean (Marston, 2009) under different archaeological and ecological contexts.

Although the use of a bivariate analysis of rank correlation among variables (such as distance, frequency or value) is a good method for modeling how human decision-making processes occur, some constraints may also limit the results of this approach. For example, giving an objective technological value to each taxon is still not a straightforward procedure, primarily because the literature in which these kinds of data are found is difficult to locate and obtain. Additionally, values may be subjective and ranks may change depending on factors other than those derived from the taxonomy (e.g., season, humidity or size of the material). Finally, conflicting situations may require appraisal of the situation from a more complex perspective because multiple criteria may influence human behavior.

\section{Acknowledgments}

JMR and LH contributed equally to this paper. We would like to thank César Morales del Molino for his constructive comments and his thorough revision of the English manuscript, Santiago Vignote (UPM) for providing guidance on wood technology and Salvia García for her statistical advice. We are also grateful to two anonymous reviewers for their helpful suggestions on the earlier draft of this article. LH held pre-graduated grants from the UVA and UPM. Funding was provided by grants from the Ministerio de Ciencia e Innovación, Spain (projects CGL2008-06005/BOS-SENSCOM-, HAR2010-21745-C03-01 and CGL2009-06988-IBERVELD) and from the Junta de Castilla y León. Preliminary results of this work were presented as a poster at the Symposium "Recostruction of Past Cultural Landscapes and Human-Related Environmental Changes Using Palynological and Archaeobotanical Records" whose convenors were Anna Maria Mercuri and Laura Sadori (12th International Palynological Congress and 8th International Organisation of Palaeobotany Conference, Bonn, August 30 - September 5, 2008).

\section{References}

Allué, E., 2003. Les anàlisis antracològiques a Tarragona i el seu entorn: l'interès per l'estudi de la vegetació del passat i la utilització dels recursos forestals. Butlletí Arqueològic 25, 5-17.

Alonso, N., 1999. De la llavor a la farina. Els processos agrícoles protohistòrics a la Catalunya occidental. Monographies d'Archéologie Méditerranéenne Lattes.

Álvarez, J., Bartolomé, C., Peinado, M., 1990. Los sabinares albares de la provincia de Guadalajara. Wad-al-hayara 17, 381-390.

Álvarez-Sanchís, J.R., 2005. Oppida and Celtic society in western Spain. e-Keltoi. Journal of Interdisciplinary Celtic Studies 6, 1-31.

Asouti, E., Austin, P., 2005. Reconstructing woodland vegetation and its exploitation by past societies, based on the analysis and interpretation of archaeological wood charcoal macro-remains. Environmental Archaeology 10, 1-18.

Badal, E., 1992. L'anthracologie préhistorique: a propos de certains problemes méthodologiques. Bulletin de la Société Botanique de France 139, 3.

Badal, E., Bernabeu, J., Vernet, J.L., 1994. Vegetation changes and human action from the Neolithic to the Bronze Age (7000-4000 BP) in Alicante, Spain, based on charcoal analysis. Vegetation History and Archaeobotany 3, 155-166. 
Bhatt, B.P., Todaria, N.P., 1992. Fuelwood characteristics of some mountain trees and shrubs. Commonwealth Forestry Review 71, 183-185.

Blanco, E., 1998. Diccionario de etnobotánica segoviana, Ayuntamiento de Segovia, Caja de Ahorros y Monte de Piedad de Segovia, Diputación Provincial de Segovia y Junta de Castilla y León, Segovia.

Blanco, J., 2003. Nuestros bosques en Castilla y León: su historia y evolución. Junta de Castilla y León, Valladolid.

Bossel, U., 1980. Heizen mit Holz. Tagungsbericht 84, 85-117.

Buxó, R., Piqué, R., 2008. Arqueobotánica. Los usos de las plantas en la Península Ibérica. Ariel Prehistoria, Barcelona.

Calonge, G., Ramos, J.M., 2006. Repoblaciones y protecciones de los encinares ibéricos hasta el siglo XX. Ejemplos expresivos de Castilla y León. Investigaciones Geográficas 41, 33-48.

Camps, M., Marcos, F., 2008. Los Biocombustibles. Mundi-Prensa Libros, Madrid.

Carrión, Y., 2005. La vegetación mediterránea y atlántica de la Península Ibérica: nuevas secuencias antracológicas. Diputación de Valencia.

Ceballos, L., Ruiz de la Torre, J., 1971. Árboles y arbustos de la España peninsular Instituto Forestal de Investigaciones y Experiencias, Madrid, Spain.

Chabal, L., 1992. La représentativité paléoecologique des charbons de bois archéologiques issus du bois de feu. Bulletin de la Societe Botanique de France-Lettres Botaniques 139, 213-236.

Chabal, L., 1997. Forêts et sociétés en Languedoc (néolithique final, antiquité tardive): l'anthracologie, méthode et paléoécologie. Editions de la Maison des sciences de l'homme, Paris.

Chabal, L., Fabre, L., Terral, J.F., Théry-Parisot, I., 1999. L'anthracologie. In: Bourquin-Mignot, C., Brochier, J.E., Chabal, L. (Eds.), La Botanique. Errance, Paris, pp. 43-95.

Cigalat, E., Soler, M.B., 2003. Guía de las principales maderas y de su secado. AMV ediciones, Madrid.

Conedera, M., Krebs, P., Tinner, W., Pradella, M., Torriani, D., 2004. The cultivation of Castanea sativa (Mill.) in Europe, from its origin to its diffusion on a continental scale. Vegetation History and Archaeobotany 13, 161-179.

Cubero, C., 2000. Estudio arqueobotánico de macrorrestos vegetales del yacimiento de las Hoya Quemada (Mora de Rubielos, Teruel). Teruel 88-89, 179-188.

Delibes, G., Romero, F., Morales, A., 1995. Arqueología y Medio ambiente: el primer milenio a. C. en el Duero medio. Junta de Castilla y León, Valladolid.

Díez, A., Bateman, M.D., López-Sáez, J.A., Vegas, J., 2002. Procesos eólicos tardiglaciares en la submeseta septentrional: Cronología del manto arenoso de la Tierra de Pinares. In: Pérez, A., Vegas, J., Machado, M.J. (Eds.), Aportaciones a la Geomorfología de España en el Inicio del Tercer Milenio, pp. 167-175.

Domínguez, Bravo, J., Ciria, P., Esteban, L.S., Sánchez, D., Lasry, P., 2003. Evaluación de la biomasa potencial como recurso energético en la región de Navarra (España). GeoFocus (Informes y Comentarios) 3, 1-10.

Dufraisse, A., 2008. Firewood management and woodland exploitation during the late Neolithic at Lac de Chalain (Jura, France). Vegetation History and Archaeobotany $17,199-210$

Figueiral, I., 1993. Charcoal analysis and the vegetational evolution of North-West Portugal. Oxford Journal of Archaeology 12, 209-222.

Figueiral, I., 1996. Wood resources in north-west Portugal: their availability and use from the late Bronze Age to the Roman period. Vegetation History and Archaeobotany 5, 121-129.

Figueiral, I., Bettencourt, A.M.S., 2004. Middle/Late Bronze Age plant communities and their exploitation in the Cávado Basin (NW Portugal) as shown by charcoal analysis: the significance and co-occurrence of Quercus (deciduous) - Fabaceae. Vegetation History and Archaeobotany 13, 219-232.

Franco, F., García-Antón, M., Maldonado, J., Morla, C., Sainz, H., 2001. The Holocene history of Pinus forests in the Spanish northern Meseta. The Holocene 11, 343-358.

Franco, F., García-Antón, M., Maldonado-Ruiz, J., Morla-Juaristi, C., Sainz-Ollero, H. 2005. Ancient pine forest on inland dunes in the Spanish northern meseta. Quaternary Research 63,1-14.

García, L., Guindeo, A., 1988. Anatomía e identificación de las maderas de coníferas españolas. AITIM, Madrid.

Gil, L.A., 2008. Pinares y rodenales. La diversidad que no se ve. Real Academia de Ingeniería, Madrid.

Graves, H.S., 1919. The Use of Wood for Fuel. Department of Agriculture, Washington, D.C.

Greguss, P., 1955. Identification of Living Gymnosperms on the Basis of Xylotomy. Akadémiai Kiado, Budapest.

Guerra, J.C., Fernández, A.A., 2001. Sistemas tradicionales de ordenación forestal en los Montes de Torozos (Valladolid-Palencia/España). Actas del III Congreso Forestal Español, Granada.

Haro, S., 2002. El poblado de Los Villares (Caudete de las Fuentes): datos ecológicos y etnobotánicos durante el Ibérico Pleno II a través de la antracología. IV. Congreso Nacional de Arqueometría, Valencia.

Jacquiot, C., 1955. Atlas d'anatomie des bois des conifères. Centre Technique du Bois, Paris.

Mariscal, B., 1995. Análisis polínico de los yacimientos de la Edad de Hierro de E Soto de Medinilla (campaña 1989-1990) y El Cerro de la Mota en Medina de Campo, Valladolid. In: Delibes, G., Romero, F., Morales, A. (Eds.), Arqueología y Medio ambiente: el primer milenio a. C. en el Duero medio. Junta de Castilla y León, pp. 337-350.

Mariscal, B., Uzquiano, P., Cubero, C., 1995. Paisaje y recursos del valle del Duero durante el primer milenio antes de Cristo a través de la Paleoetnobotánica. In:
Delibes, G., Romero, F., Morales, A. (Eds.), Arqueología y Medio ambiente: el primer milenio a. C. en el Duero medio. Junta de Castilla y León, pp. 417-454.

Marston, J.M., 2009. Modeling wood acquisition strategies from archaeological charcoal remains. Journal of Archaeological Science 36, 2192-2200.

Mata, C., 1991. Los Villares (Caudete de las Fuentes, Valencia). Origen y evolución de la cultura ibérica, Serie de Trabajos Varios del Servicio de Investigación Prehistórica. Diputación de Valencia.

McLeod, A.I., 2005. Kendall rank correlation and Mann-Kendall trend test. R Package Version. 2.1. http://www.stats.uwo.ca/faculty/aim (accessed 2010).

Moreno, E., Iglesias, R., Hernández, L., Rubiales, J.M., Morales, C., Gómez Manzaneque, F., et al., 2009. Huellas de la presencia pasada de pinares montanos en la submeseta norte de la Península Ibérica: Tubilla del Lago y Tubilla del Agua. $5^{\circ}$ Congreso Forestal Nacional, S.E.C.F.-Junta de Castilla y León, Ávila.

Nuñez-Regueira, L., Rodríguez Añón, J.A., Castineiras, J.P., 1997. Calorific values and flammability of forest species in Galicia. Continental high mountainous and humid Atlantic zones. Bioresource Technology 61, 111-119.

Nuñez-Regueira, L., Rodriguez-Añón, J., Proupín-Castiñeiras, J., Romero-García, A., 2001a. Energetic evaluation of biomass originating from forest waste by bomb calorimetry. Journal of Thermal Analysis and Calorimetry 66, 281-292.

Nuñez-Regueira, L., Rodríguez-Añón, J.A., Proupín-Castiñeiras, J., Nunez-Fernandez, O., 2001b. Calculation of forest biomass indices as a tool to fight forest fires. Thermochimica Acta 378, 9-25.

Oliver, A., 2006. El Puig de la Nau, Benicarló. Proyecto Cultural de Castellón, Castellón.

Oria de Rueda, J.A., 2007. Principales especies forestales. In: Atlas forestal de Castilla y León. Junta de Castilla y León, León, pp. 35-51.

Oria de Rueda, J.A., Díez, J., 2002. Guía de árboles y arbustos de Castilla y León, Cálamo, Palencia.

Peraza, C., 1964. Estudio de las maderas de coníferas españolas y de la zona norte de Marruecos, Ministerio de Agricultura. Instituto Forestal de Investigaciones y Experiencias, Madrid.

Piqué, R., 2005. Paisaje y gestión de recursos forestales entre el VI y IV milenio cal BC en el nordeste de la Península Ibérica. Actas del III Congreso del Neolítico en la Península Ibérica: Santander, 5 a 8 de octubre de 2003, Servicio de Publicaciones de la Universidad de Cantabria.

Piqué, R., Pons, E., 2007. Paisatge i assentament en el jaciment ibèric de Mas Castellar de Pontós (Alt Empordà): l'explotació del combustible vegetal al'Alt Empordà en el primer millenni aC. Actes Congrés sobre el Paisatge. Annals de l'Institut d'Estudis Empordanesos, pp. 217-232.

Piqué, R., Ros, M.T., 2002. La gestió dels recursosllenyosos entre els segles VI-II aC. In: Pons, E. (Ed.), Mas Castellar de Pontós (Alt Empordà). Un complexarqueològic d'època ibèrica (excavacions 1990-1998). Monografies del Museu d'Arqueologia de Catalunya, Girona, pp. 429-442.

Ramos, J.M., 2005a. Fuentes historiográficas para el estudio e interpretación de los montes y sus aprovechamientos: su aplicación en Castilla y León (siglos XVI-XX). Investigaciones Geográficas 36, 43-59.

Ramos, J.M., 2005b. Intervención humana y transformación de los paisajes forestales en la Cuenca del Duero durante la Edad Moderna. Papeles de Geografía 41, 209-223.

Reisinger, K., Haslinger, C., Herger, M., Hofbauer, H., 2009. BIOBIB, a Database for Biofuels. Institute of Chemical Engineering, Fuel and Environmental Technology. University of Technology, Vienna. http://www.vt.tuwien.ac.at/biobib.

Rocafiguera, M., 2005. Arquitectura ibèrica ausetana. Materials i tècniques de construcció al jaciment de l'Esquerda (segle V a. C.). Fonaments 12, 235-250.

Rodríguez, E., 2008. Procedencia y uso de madera de pino silvestre y pino laricio en edificios históricos de Castilla y Andalucía. Arqueología de la Arquitectura 5, 33-53.

Romero, F., Sanz, C., Escudero, Z., 1993. Arqueología Vaccea. Estudios sobre el mundo prerromano en la Cuenca media del Duero. Junta de Castilla y León, Valladolid.

Rubiales, J.M., García-Amorena, I., Génova, M., Gómez Manzaneque, F., Morla, C., 2007. The Holocene history of highland pine forests in a submediterranean mountain: the case of Gredos mountain range (Iberian Central range, Spain). Quaternary Science Reviews 26, 1759-1770.

Ruiz de la Torre, J., 1990-1998. Mapa Forestal de España 1:200.000, ICONA. Escuela Técnica Superior de Ingenieros de Montes, Madrid.

Ruiz de la Torre, J., 2002. Mapa forestal de España. Escala 1:1.000.000. Organismo Autónomo Parques Nacionales, D.L., Madrid.

Ruiz Zapata, M.B., 1995. Análisis polínico del yacimiento de Soto de Medinilla: campaña de 1986-87 en el poblado vacceo. In: Delibes, G., Romero, F., Morales, A. (Eds.), Arqueología y Medio ambiente: el primer milenio a. C. en el Duero medio. Junta de Castilla y León, pp. 351-356.

Sanz, C., Velasco, J., 2003. Pintia. Un oppidum en los confines orientales de la región vaccea. Universidad de Valladolid, Valladolid.

Sanz, C., Romero, F., Górriz, C., 2009. Espacios domésticos y áreas funcionales en los niveles sertorianos de la ciudad vacceo-romana de Pintia (Padilla de Duero Peñafiel, Valladolid). In: Belate (Ed.), L'espai domèstic i l'organització de la societat a la protohistòria de la Mediterrània occidental (1er millenni $\mathrm{aC}$ ): actes de la IV Reunió internacional d'Arqueologia de Calafell. Calafell-Tarragona, March 2007.

Schweingruber, F., 1990. Anatomy of European Woods, WSL/FNP. Paul Haupt Berne \& Stuttgart, Stuttgart.

Siafaca, L., Adamandiadou, S., Margaris, N.S., 1980. Caloric content in plants dominating maquis ecosystems in Greece. Oecologia 44, 276-280.

Smart, T.L., Hoffman, E.S., 1988. Environmental interpretation of archaeological charcoal. In: Hastorf, C.A., Popper, V.S. (Eds.), Current Paleoethnobotany: 
Analytical Methods and Cultural Interpretations of Archaeological Plant Remains. University Of Chicago Press, pp. 165-205.

Théry-Parisot, I., 2001. Economie des combustibles au paléolithique: expérimentation, taphonomie, anthracologie. CNRS.

Théry-Parisot, I., Chabal, L., Chrzavzez, J., 2010. Anthracology and taphonomy, from wood gathering to charcoal analysis. A review of the taphonomic processes modifying charcoal assemblages, in archaeological contexts. Palaeogeography, Palaeoclimatology, Palaeoecology 241, 142-153.

Tolosana, E., Ambrosio, Y., Laina, R., Martínez, R., 2008. Sistemas de aprovechamiento de biomasa en Castilla y León. Boletín del CIDEU 5, 97-106.

Uzquiano, P., 1995. El valle del Duero en la Edad del Hierro: el aporte de la Antracología. In: Delibes, G., Romero, F., Morales, A. (Eds.), Arqueología y Medio ambiente: el primer milenio a. C. en el Duero medio. Junta de Castilla y León, pp. 395-416.

Uzquiano, P., Arnanz, A.M., 1997. Consideraciones paleoambientales del Tardiglaciar y Holoceno inicial en el Levante español: macrorrestos vegetales de El Tossal de la Roca (Vall d'Alcalà, Alicante). Anales del Jardín Botánico de Madrid 55, 125-133.
Velasco, J., Sanz, C., Centeno, I., 2003. La necrópolis tardoantigua e hispanovisigoda de Las Quintanas. In: Sanz, C., Velasco, J. (Eds.), Pintia. Un oppidum en los confines orientales de la región vaccea. Investigaciones arqueológicas Vacceas, Romanas y Visigodas (1999-2003). Universidad de Valladolid, Valladolid.

Vernet, J.L., 1997. L'homme et la forêt méditerranéenne: de la préhistoire à nos jours. Errance, Paris.

Vernet, J.L., Ogererau, P., Figueireal, I., Machado Yanes, C., Uzquiano, P., 2001. Guide d'identification des charbons de bois préhistoriques et récents: Sud-ouest de l'Europe: France, Peninsule Ibérique et Îles Canaries. CNRS.

Viquerat, P.A., Beck, J., Lachal, B., Pampaloni, E., Sella, F., 2006. Valorisation ernergetique des bois flottants de verbois. Caractérisation physico-chimique de la ressource et étude des filières. Université de Genève, Carouge-Genève.

Wattenberg, F., 1959. La Región Vaccea. Celtiberismo y romanización en la cuenca media del Duero. Biblioteca Praehistorica Hispanica, I, Madrid.

Yll, E., 1995. Análisis polínico de los yacimientos de la Edad del Hierro de Soto de Medinilla, La Era Alta y La Mota (Valladolid). In: Delibes, G., Romero, $F$ Morales, A. (Eds.), Arqueología y Medio ambiente: el primer milenio a. C. en el Duero medio. Junta de Castilla y León, pp. 357-370. 